\title{
Transformation of Turkey's Civil-Military Relations Culture and International Environment
}

\author{
Ali L. Karaosmanoğlu
}

To cite this article: Ali L. Karaosmanoğlu (2011) Transformation of Turkey's Civil-Military Relations Culture and International Environment, Turkish Studies, 12:2, 253-264, DOI: 10.1080/14683849.2011.572632

To link to this article: http://dx.doi.org/10.1080/14683849.2011.572632

曲 Published online: 01 Jul 2011.

Submit your article to this journal $\pi$

Џlll Article views: 676

Q View related articles $\asymp$

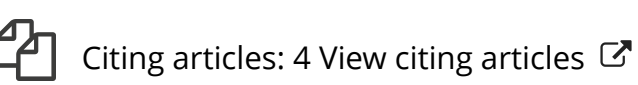




\title{
Transformation of Turkey's Civil-Military Relations Culture and International Environment
}

\author{
ALİ L. KARAOSMANOĞLU \\ Professor Emeritus of International Relations, Bilkent University; \\ Director, İhsan Doğramacı Foundation Center for Foreign Policy and Peace Research
}

\begin{abstract}
In Turkey, civil-military relations are often understood and explained from a binary and confrontational perspective. Although this conceptual framework is not completely irrelevant, it is far from being adequate to explain the close collaboration that has characterized civil-military relations since 2007. The principal reason for this gap in the literature is that the mainstream approach overemphasizes the power political aspect of civilmilitary relations while it overlooks their historical-cultural and international-structural dimensions.
\end{abstract}

Civil-military relations in Turkey have recently taken a turn towards further democratization. This development is different from the previous reforms which were adopted by the Justice and Development Party (AKP) government from 2002 to 2006 for the purpose of harmonization with the European Union (EU). This time the change is unfolding to some extent independently of Ankara's European vocation. The new pattern is characterized by close and effective collaboration between the civilian government and the military.

Although the EU reforms had brought Turkey more in line with democratic norms and practices, public declarations of political significance by military leaders in 2006 and 2007 demonstrated the continuing influence of the Armed Forces on public affairs. On April 27, 2007, the Chief of General Staff General Yaşar Büyükantt's encroachment on the presidential election through an "electronic ultimatum" was a blatant example of the continuing political role of the Turkish Armed Forces (TAF). That ultimatum of General Staff, however, was promptly and strongly refuted by the government. ${ }^{1}$ The landslide victory of the AKP in the general election of July 2007 consolidated the legitimacy of the government even further.

Correspondence Address: Ali L. Karaosmanoğlu, İstinye Park Residence, Erguvan-B, Daire 12, 34460 İstinye, Istanbul, Turkey. Email: alikaraosmanoğlu@gmail.com. 
These developments led to a perplexing turn in civil-military relations. Many people in the country and abroad were expecting the confrontation to result in a coup d'état or, at least, in a heavy military encroachment upon politics. Remarkably, none of these happened. Instead, there was an emergence of a new pattern which was marked by common understanding and an implicit but effective collaboration between the civilian government and the military. According to many people, a Prime Minister with Islamic roots and the laicist generals was unlikely to meet almost every week in addition to their official routine meetings. What was believed to be clear turned out to be anything but clear. This unexpected propinquity between Prime Minister and High Command posed a disturbing puzzle: what might account for this new pattern?

The mainstream approach to civil-military relations in Turkey is generally based on power relations. That approach often starts from a dichotomy between the secular, patriotic, rational and modern soldier versus the elected, but inefficient and antisecularist politician. ${ }^{2}$ This assumption has often been used to rationalize military takeovers and other lesser military interventions in politics.

Some academics and columnists believe in the necessity of military guardianship because, according to them, the population is not yet educated and mature enough to elect the "right" politicians. They also argue that the military's interference with politics should continue and should be accepted as an indispensable part of the constitutional regime in a country like Turkey. ${ }^{3}$ Those analysts who are critical of the military's influence on politics also predicate their arguments on a similar binary assumption by underlining conflict-ridden aspects of the relationship between the military and the civilian elite. They regard civil-military matters mainly as "power relations that involve constant confrontation and tension." Therefore, "civil-military relations are power relations because they refer to a conflict about who will have the upper hand when it comes to contentious issues." It is further argued that civilian politicians give their consent for the demands of the military and "even seek an enhanced role for the military." "The problem, therefore, according to that approach "is not just the implementation of the democratic control of the armed forces, but the larger one of civilian empowerment, that is, enabling civilian governments to take control over not only the military universe but also the life of the country, the economy, political process, institutional make-up, [and the like]."7 It is assumed that the military by its very nature tend to dominate all of the above. Some scholars have pushed this kind of analysis to the extreme by asserting that the TAF's propensity "to make and break governments does not seem at all a passing phenomenon." 8 The main instrument of the military in maintaining and expanding its influence over politics has been its undue attribution of primacy to the internal security issues such as "Islamic activism and Kurdish nationalism" over the external threats. ${ }^{9}$

Such arguments, however, have not been readily acceptable to some scholars and analysts. As early as 2005 a Report by the Centre for European Security Studies (CESS) criticized the general European perceptions of the Turkish military's political role as exaggerated and simplistic. The Report criticized the view that the TAF was "a 
state within a state for all practical purposes." The Report stated that it was "a caricature of present-day Turkey, not only unflattering but ... inaccurate."10

In a recent Adelphi Paper, Karabekir Akkoyunlu points out:

It would be misleading to look at Turkish democratization from a binary perspective, juxtaposing an authoritarian military against democratically inclined civilian politicians. Turkish democratization is best studied through a holistic approach that analyses the evolution of democratic political culture in Turkey. ${ }^{11}$

Although the binary analyses have long been reflective of certain aspects of the Turkish case, their explanatory value is increasingly fading away as a result of the above-mentioned trends which require a new paradigm for their clearer comprehension and explanation. The binary and power-based approaches, however scholarly, overlook the highly interactive and transformative character of civil-military relations. They minimize the possibility of collaboration and institutional-functional interpenetration in a fairly large setting of shared understandings that derive from Turkey's historical and political context. ${ }^{12}$ The civil authority needs the armed forces for the defense of the state and the country's territorial integrity. In return, the armed forces need the civil authority for the recognition of their own legitimacy in accordance with fundamental democratic principles. ${ }^{13}$ The main issue then is not a simple maximization of civilian power over the armed forces. The real problem is "how to maintain a strong and effective military that poses no threat to the civilian elite."14 This problem can be effectively managed by bringing about an appropriate collegial relationship between the military and civilian elites. ${ }^{15}$ After all, an effective control of the military depends on the cooperation of the officer corps with the civilian government and vice versa. Both function within the same state structure and need each other.

Moreover, given the organizational and functional specificities of the military institution and the fusion of internal and external security in the contemporary world, no civilian authority can afford to overlook the growing significance of the military input in political decision making. This question has recently come to the forefront particularly in Great Britain and the United States because of the war on terror and invasion of Iraq. General Sir Richard Dannett's criticism of his government's decision to invade Iraq was probably an unprecedented act of insubordination for a serving head of the army in a highly liberal democratic country such as the United Kingdom. This incident, however, marked the need for a new type of civil-military relations. Sir Richard's complaints also echoed the restiveness of the military in the US. ${ }^{16}$ In the same year, Hew Strachan published a piece in Survival, criticizing approaches that regard armed forces simply as an instrument of the civilian government without due consideration of the nature and capabilities of that instrument. Strachan stressed the significance of the "dialogue between politicians and soldiers and ... the harmonization of the two elements." ${ }^{17}$ Strachan further suggested: "The principle we need to embrace is that of civil-military integration, founded on the 
notions of equality in council and of harmonization of effects." ${ }^{18}$ Such a revised system of civil-military relations, according to Strachan, will reintegrate the armed forces and the government within the state structure and render the parliamentary control on both the civilian and military agents of the executive more effective. Thus, it will help improve the smooth functioning of the democratic regime, because the last word will still belong to civilian government. ${ }^{19}$

In the contemporary world, the political and military spheres are interpenetrating more than ever. Civil-military relations should not be considered as a conflictridden relationship. Political and military leaders are expected to collaborate in reaching a constructive consensus not only on defense and security policies, but also on how to manage their relationship within the state and society. These views that are nowadays being debated in liberal democracies such as the United States and Great Britain are equally relevant for a country such as Turkey, which is working to consolidate its democracy in a highly challenging security environment.

\section{International-Structural Dimension}

The mainstream approach to the Turkish case focuses on internal political factors and ignores the broader security environment and international factors. On the one hand, the rising ethnic separatism combined with regional security challenges involving extra-regional forces such as the invasion of Iraq by the US and, on the other hand, the rising democratic and liberal values as a result of globalization have blurred the demarcation line between the internal and the international. This development has brought about the international dimension alongside the internal dimension of security challenges and made the military and civilian outlooks externally as well as politically oriented. Moreover, we are witnessing today an "aggregation of different conflicts" 20 in the Middle East. This is the result of a structural systemic development instead of a securitization discourse, blaming external actors for internal security problems. The convergence of different security challenges emanating both from inside and outside has brought the political and other non-military aspects of conflict to the forefront.

Michael Desch studied the impact of international and internal security environments on civil-military relations in the US, the Soviet Union and the Latin American countries. According to his findings, "in challenging external security environment civilian and military ideas will converge" ${ }^{21}$ and this will facilitate the civilian control of the military. Conversely, "challenging domestic threat environments would produce internally-oriented military doctrines which inevitably lead to serious weaknesses in civilian control of the military." ${ }^{22}$ The interaction of internal and external structural factors and the degree of their influence will shape the patterns of civilian control of the military. ${ }^{23}$ In such situations, we should look at variables such as the military doctrine,${ }^{24}$ historical experiences, security culture, and the military mindset.

The Kurdish separatism and the PKK (Kurdistan Workers' Party), accepted as a terrorist organization by the international community, represented not only a 
domestic threat, but also posed an international threat with growing regional and extra regional involvements. The ultimate aim of the PKK has always been political. In the 1970s, it was created as a revolutionary Marxist-Leninist organization whose aim was to set up a "democratic and united Kurdistan" in southeastern Turkey. ${ }^{25}$ During the first decades of the PKK's development, the politicians and the military had difficulty to correctly diagnose the nature and capacities of that organization. The officials had the habit of calling it as a "handful of bandits" (bir avuç eşkiya) ${ }^{26}$ This lack of understanding led the governments to completely transfer the responsibility of dealing with the PKK to the TAF, detaching the conflict from its political context.

In the meantime, the PKK became a typical transnational terrorist organization with many connections, support bases, and propaganda centers in the Middle East and Europe. ${ }^{27}$ In the aftermath of the first Gulf War, the demise of the Iraqi government north of the thirty-sixth parallel complicated Turkey's security considerations. The region became a sanctuary for the PKK terrorists, who began to operate from northern Iraq. Between the two Gulf Wars, the TAF operated in the Iraqi territory nearly seventy times to hit the PKK camps and disrupt their logistic lines. All these operations remained within the purview of the military and were called "internal security operations." without any strategic link between them and politics and between internal and international.

Another aspect of the changing political context is that Turkey is passing through a radical transformation. It initiated an extensive program of liberalization and restructuring reforms in law, politics and economy. These measures are motivated by a desire for further democratization. The reforms include inter alia measures broadening cultural rights and freedoms of expression and association. The extraordinary security measures which had been adopted in the southeastern regions of the country were lifted. The military consented to those reforms. Prime Minister at the time, Abdullah Gül extended his gratitude to the military for their collaboration and support: "The TAF made valuable contributions to our EU objectives and reforms. They would have been much more difficult to carry out without the support of the military. The TAF well appreciate what Turkey's interests are. They have a long-term strategic vision." ${ }^{28}$ The liberalization of politics as a result of reforms encouraged debate on the Kurdish question and the struggle against the PKK by bringing the political aspects of these issues to the forefront.

Another development affecting civil-military relations took place after the second Gulf War. In 2007 and 2008, the air and land forces undertook fifteen cross-border operations against PKK targets in northern Iraq. Before the launching of the operations, the government worked hard to prepare a favorable political and diplomatic environment in the US, Europe, and the Middle East. Since then Prime Minister Erdoğan and the Chief of General Staff have been getting together almost weekly in official and unofficial settings to discuss and evaluate operations and other security problems. One of the summit declarations in early June 2007 emphasized that the fight against terrorism would be carried out "on the basis of democracy and rule of law." 29 It also said that there was "full harmony and coordination" between the government and the armed forces. ${ }^{30}$ This collegial relationship between the civil 
government and the military created not only a window of opportunity for further democratization, but it also underlined the significance of the strategic interaction between politics and military operations. Furthermore, it brought to the forefront the inescapable political dimension of counter-terrorism and the Kurdish problem. Two factors motivated civil-military collaboration; before and during the operations, the need to maintain national solidarity became an issue of high priority. The military wanted to avoid any steps that would split the nation between the Kurds and Turks. Two days before the general elections of July 2007, Foreign Minister at the time, Abdullah Gül made a declaration saying that there was no rift between the TAF and the government and the damage caused by the "electronic ultimatum" of the General Staff was already "repaired." ${ }^{\prime 1}$ Secondly, and probably more significantly, a change of approach to the struggle against the PKK has occurred. The relative internationalization of the PKK issue and the Kurdish problem on the one hand, and their convergence with the complex warfare in Iraq, on the other hand, aggregated diverse security challenges emanating both from inside and outside. This development has made the political and other non-military dimensions increasingly visible. Moreover, the revival of the PKK despite successful military operations in the 1990s reconfirmed the need to subordinate military operations to a new comprehensive understanding by integrating military and political efforts for economic, diplomatic, social-psychological, and public relations measures. ${ }^{32}$ Such an approach would naturally require a close collaboration between the military and the civilian government. Notwithstanding the ongoing civil-military cooperation, as of Spring 2011, there are no signs that the government has yet formulated a comprehensive policy on the Kurdish question.

\section{Historical-Cultural Dimension}

The conflict-oriented approach tends to detach itself from the historical and cultural context, too. It reduces the complexities of the Ottoman-Turkish modernization to a simplistic dichotomy. Civil-military relations in every country, however, occur and develop "under the guidance of cultural patterns," which are "historically created systems of meaning in terms of which we give form, order, point, and direction to our lives. ${ }^{\prime 33}$ In civil-military research and security studies, cultural approach is becoming increasingly important. ${ }^{34}$

According to Colin Gray, security culture "change over time, as new experience is absorbed, coded and culturally translated." ${ }^{35}$ Culture is not insular. Cultures interpenetrate and take new forms, albeit slowly. The question, therefore, is not whether a particular national security culture is changeable or not. The question is about the direction, quality, and degree of change. Culture changes through inter-subjective processes within communities and between communities.

Turkey has a deep-rooted security culture which has been shaped by the accumulation of historical experiences and interpenetration of diverse kinds of discourses both under the Ottoman Empire and the Republic. ${ }^{36}$ Turkey's responses to security challenges from within and without, and thus civil-military relations, are profoundly 
affected by its security culture as much as by material structural factors such as power configurations in the international system. Turkey's security culture has paradoxical characteristics. While some of these characteristics are facilitating the democratization of civil-military relations, the others are complicating democratic processes. Civil-military relations in Turkey cannot be defined as a linear development of cultural change. It has been (and is being) formed as a four-layered political-military construction.

First of all, the Ottoman and Republican security cultures have been state-centric. The Ottomans, from the second half of the eighteenth century onwards, implemented a reform policy in the public bureaucracy and military institution. The primary purpose of the modernizing reforms was to strengthen the state in the face of the threats emanating from the great powers of Europe and the detractors of those reforms in the Empire. The survival of the state depended on its ability to adapt to changing circumstances. ${ }^{37}$ The armed forces were the first institution that underwent radical reforms. The Palace assigned the modernized military the task of protecting the reforms against "the internal enemies," which were presumably the traditionalists and extremist religious groups. The modernized military, however, exercised from time to time this role of guardianship against the Throne as well. This practice was gradually internalized by the military and other state elites and was inherited by the Republic. The crux of the dominant discourse has always been "the preservation of the state."

Another dimension of the Ottoman-Turkish political culture has been "the interactive or dialogical dimension" of "clashes between alternative frameworks of meaning" in which "the two horizons fused together." 38 The ability and possibility of this dialogical process have survived in the sinews of the state under the Republic. Şerif Mardin has made us understand this phenomenon in the most eloquent way:

The history of modern Turkey is not that of a conflict between republicanism and Sultanism, nor is it a history of the strife framed by Islam and secularism. It is a complex, many-tiered encounter between "traditional" forces and modernity that have interpenetrated and been transformed over time due to their propinquity. It is also a story of the constitution of new spaces where these forces have met and changed. ${ }^{39}$

This interpenetration has legitimized change and facilitated their adaptation to modernity. ${ }^{40}$ The spaces of shared understanding were constituted by the state and for the state, the common objective being the adjustment of the state to the changing environment to ensure its preservation. Within this continual process of adaptation, in spite of occasional ruptures, there have been long periods of collegial relationship between civilians and officers in the Turkish Republic. In those periods civilmilitary relations operated on a fairly effective democratic basis. The Turkish War of Independence (1919-1922), Turkey's alignment with NATO (1952) and the Democrat Party period (1950-1960) which ended with a military coup, the Özal 
period (1983-1993), and the period of the EU reforms from 2002 to 2006 can be mentioned as conspicuous examples.

The third layer was formed under the impact of the wave of democratization that spread in the Western world after World War II. Turkey adopted the multiparty system in 1945. The TAF were divided on the transition to democracy. A number of officers were concerned about the risks of democracy because they believed that it would be difficult to maintain the republican principles, particularly laicism, in a democratic polity. Another group of officers were in favor of a multiparty system. They believed that the democratic transformation would facilitate Turkey's admission to NATO. ${ }^{41}$

As a result of the transition to democracy, the military found itself in a dilemma. Democracy had emerged as an indispensable element of modernization. Democracy, however, had brought about ideological fault lines and social, economic and political interests to the center stage. Moreover, what seemed more ominous was that it tended to make religion increasingly visible as a social force. The officers, confronted with this challenge, adopted an ambivalent position towards democracy. On the one hand, the military agreed to democratization, on the other hand, it maintained its guardianship role. Although democracy (and modernity) implied civilian primacy, the military refrained from acting as an agent of the civilian government because the officers believed that subordination to civilian politicians would prejudice their role of guardianship. ${ }^{42}$ The generals' declarations interestingly reflect this dilemma. ${ }^{43}$ Even the most democratically oriented generals in the 2000s, such as General Hilmi Özkök, seemed to be unable to escape from the dilemma. General Özkök believed that Article 35 of the Internal Service Law is necessary and it should not be abolished. That article authorizes the TAF to intervene in politics ex officio to protect the constitutional regime whenever it deems necessary. Nevertheless, he said that he would prefer non-coercive, diplomatic ways of intervention. ${ }^{44}$

The fourth layer is being constructed by the opening of channels of communication and monitoring between the TAF and other institutions, public and private, at the national and international levels. There is a growing pressure for further democratization from the certain segments of the population as well as from certain nongovernmental organizations and intelligentsia. Political statements of the Chiefs of General Staff and force commanders spark heated critical debates in the media. Many columnists and academics severely criticize such statements as unjustified interventions in politics. Political Science and International Relations departments at higher institutions of learning and think tanks take an increasing interest in security studies and civil-military relations. The generals are also beginning to be interested in such issues. ${ }^{45}$ Turkey's voluntary participation in peace operations after the Cold War should be expected to contribute to the transformation of the military mindset in line with emerging security conceptualizations suggesting human and societal dimensions of security.

Turkey's candidacy for the EU membership has also opened new channels of communication with democratic countries at both societal and state levels. Despite the present unsatisfactory state of EU-Turkey relations, both parties continue to make 
use of the channels of communication to contribute to the democratization of civilmilitary relations in Turkey.

\section{Conclusion}

During the last decade, academic research and publication on civil-military relations have made considerable progress. The mainstream perspective, however, has remained limited to binary and power-based analyses. This perspective is not totally irrelevant because civil-military relations undoubtedly have a confrontational power political aspect. However, since the mainstream approach in Turkish literature has overlooked international structural changes and security culture, it proved to be inadequate to explain the periods of close collaboration between the military and the civilian government. This inadequacy was particularly palpable in the face of the perplexing propinquity between the AKP government and the TAF.

The Ottoman-Turkish modernization depended on the creation by the state of spaces of shared understanding in which dialogical encounters and interpenetrations occurred between the forces of tradition and modernity. These encounters legitimized change and facilitated the adaptation of state institutions to the changing environment as well as modernity. In other words, this aspect of Turkey's political culture refined and moderated the guardianship role of the military although modernization alienated the officers from the people to a considerable extent ... The development of civilmilitary relations in Turkey cannot be understood without giving due consideration to the historical-cultural perspective. On the other hand, the relationship which is understandable through the cultural approach should be open to explanations predicated upon international structural variables that may initially induce the state to take measures of adaptation.

As a result of the invasion of Iraq, the Middle Eastern sub-system became increasingly more complex and more challenging. The difficult security environment induced the government and the military to make efforts to develop a new strategic outlook on the Kurdish question in general and the struggle against the PKK in particular with certain political (non-military) and international overtones. Moreover, the cross-border military operations into northern Iraq required international legitimization and this could only be achieved through diplomacy. These circumstances increased the need for politics and civilian efforts, and brought the government to the forefront in security policy-making.

Since Turkey is rapidly integrating to a globalizing world and it is a member of NATO, OSCE, and a negotiating candidate to the EU membership, its civil-military relations cannot remain solely on the domestic level. International involvements are inevitable, enlarging the cultural context in which the dialogical inter-subjective process takes place. From this perspective, keeping the channels of communication with the EU open could help facilitate and expedite the reform process in Turkey as witnessed in 2002-2006.

In consolidated democracies, the civilian control of the military is taken for granted in spite of occasional derelictions of duty on the part of the military. It is internalized 
by both civilians and soldiers. In unconsolidated democracies such as Turkey, the civilian control is yet to be internalized. It is to be constructed. The military must come to believe that subordination to the civilian authority is a virtue. ${ }^{46}$ This kind of a process of construction implies a cultural change which, in turn, needs open channels of inter-subjective communication inside and outside.

\section{Notes}

1. The Cabinet spokesman Cemil Çiçek unequivocally stated that the generals are subordinated to the government and, therefore, they are not in a position to make such political statements. See Milliyet (April 29, 2007).

2. Gareth Jenkins, Context and Circumstance: The Turkish Military and Politics, Adelphi Paper 337 (Oxford: Oxford University Press/IISS, 2001), pp. 15, 21.

3. Osman M. Öztürk, Ordu ve Politika [Army and Politics] (Ankara: Fark Yayınları, 2006), pp. 147-57 and 268; Mehmet Ali Kışlalı, "Avrupa Birliği, TSK Kaygısı" [The European Union, the Concern of the Turkish Armed Forces], Radikal (November 3, 2006), p. 8.

4. For example, Tanel Demirel, "Soldiers and Civilians: The Dilemma of Turkish Democracy," Middle Eastern Studies, Vol. 40, No. 1 (January 2004), p. 145.

5. Ibid., p. 127.

6. Ibid., p. 128. For the approach, see also Ahmet Insel and Ali Bayramoğlu, eds., Türkiye'de Ordu (Istanbul: Birikim, 2004).

7. Ümit Cizre, "Democratic Control of Armed Forces on the Edge of Europe: The Case of Turkey" in Hans Born, Karl Haltiner, and Marjan Malesic, eds., Renaissance of Democratic Control of Armed Forces in Contemporary Societies (Baden-Baden: Nomos Verlag, 2004), p. 113. See also Ümit Cizre, "Ideology, Context and Interest: The Turkish Military" in Reşat Kasaba (ed.), Turkey in the Modern World (Cambridge: Cambridge University Press, 2008), pp. 301-32.

8. Cizre, "Democratic Control of Armed Forces," p. 110.

9. Ibid., pp. 104, 106. For the role of the military in "securitization," see also Kemal Kirişçi, Turkey's Foreign Policy in Turbulent Times, Chaillot Paper no. 92 (Paris: Institute for Security Studies, September 2006), pp. 32-8.

10. Wim van Eekelen (chairman) and David Greenwood (rapporteur), Turkish Civil-Military Relations and the EU: Preparation for Continuing Convergence, Final Report of a Task Force (Groningen: CESS, November 2005), p. 12.

11. Karabekir Akkoyunlu, Military Reform and Democratisation: Turkish and Indonesian Experiences at the Turn of the Millennium, Adelphi Paper no. 392 (London: Routledge/IISS, 2007), p. 36.

12. Şerif Mardin, "Turkish Islamic Exceptionalism Yesterday and Today: Continuity, Rupture and Reconstruction in Operational Codes," Turkish Studies, Vol. 6, No. 2 (June 2005), p. 146.

13. Douglas L. Bland, "Your Obedient Servant: The Military's Role in the Civil Control of Armed Forces," in H. Born, K. Haltiner, M. Malesic, eds., p. 25.

14. James Burk, "Theories of Democratic Civil-Military Relations," Armed Forces and Society, Vol. 29, No. 1 (Fall 2002), p. 15.

15. Ibid., p. 17. For contemporary theory, see also Peter D. Feaver, "The Civil-Military Problematique: Huntington, Janowitz, and the Question of Civilian Control," Armed Forces and Society, Vol. 23, No. 2 (Winter 1996), pp. 149-78; Douglas L. Bland, "Patterns in Liberal Democratic Civil-Military Relations," Armed Forces and Society, Vol. 27, No. 4 (Summer 2001), pp. 525-40; Andrew Cottey, Timothy Edmunds, and Anthony Forster, "The Second Generation Problematique: Rethinking Democracy and Civil-Military Relations," Armed Forces and Society, Vol. 29, No. 1 (Fall 2002), pp. 31-56; and Rebecca L. Schiff, "Civil-Military Relations Reconsidered: A Theory of Concordance," Armed Forces and Society, Vol. 22, No. 1 (Fall 1995), pp. 7-24. For Schiff's “concordance” theory's application to Turkey, see Nilüfer Narl, "Civil-Military Relations in Turkey," Turkish Studies, Vol. 1, No. 1 (2000), pp. 107-27. 
16. Financial Times, October 14-15, 2006, pp. 1-2, 6; and The Guardian, October 18, 2006, p. 1. For the civil-military tension in the U.S., see Michael C. Desch, "Bush and the Generals," Foreign Affairs, Vol. 86, No. 3 (May/June 2007), pp. 97-108.

17. Hew Strachan, "Making Strategy: Civil-Military Relations after Iraq," Survival, Vol. 48, No. 3 (Autumn 2006), p. 67.

18. Ibid., p. 76.

19. Ibid., pp. 79-80.

20. Hew Strachan, "Strategy and the Limitation of War," Survival, Vol. 50, No. 1 (February-March 2008), p. 34.

21. Michael C. Desch, Civilian Control of the Military: The Changing Security Environment (Baltimore: The Johns Hopkins University Press, 1999), p. 19.

22. Ibid., p. 113.

23. Ibid., pp. 6 and 15.

24. Ibid., pp. 12 and 118.

25. Nihat A. Özcan, PKK-Kürdistan İşçi Partisi: Tarihi, İdeolojisi ve Yöntemi [The PKK-The Labor Party of Kurdistan] (Ankara: ASAM, 1999), pp. 55-68.

26. Ümit Özdağ and Ersel Aydınlı, "Winning a Low Intensity Conflict: Drawing Lessons from the Turkish Case," The Review of International Affairs, Vol. 2, No. 3 (Spring 2003), p. 108.

27. Ibid., pp. 110-11.

28. Reported by Murat Yetkin, "Gül: Askerlerin AB Desteğinden Memnunuz" [Gül: We are Happy with the Military's Support to the EU Project], Radikal (June 15, 2006), p. 6.

29. Briefing (June 18, 2007), p. 6.

30. Ibid.

31. Milliyet (July 20, 2007), p. 16.

32. For the emphasis put on the non-military aspects of security, see the Opening Address of International Symposium by the Commander of Turkish Armed Forces General Yaşar Büyükanıt (Istanbul, May 31, 2007); and the Opening Address of the Academic Year 2007-2008 of the War College by the Turkish Land Forces Commander General İlker Başbuğ (Ankara, September 24, 2007). For the texts, see the website of the Turkish General Staff: http://www.tsk.tr/KOMUTANKONUSMALAR. html

33. Clifford Geertz, The Interpretation of Culture (New York: Basic Books, 1973), p. 52.

34. Mark I. Lichbach and Alan S. Zuckerman, eds., Comparative Politics: Rationality, Culture, and Structure Second edition (Cambridge: Cambridge University Press, 2009); David Pion-Berlin, ed., CivilMilitary Relations in Latin America: New Analytical Perspectives (Chapel Hill: The University of North Carolina Press, 2001); Peter J. Katzenstein, ed., The Culture of National Security: Norms and Identity in World Politics (New York: Columbia University Press, 1996).

35. Colin S. Gray, Modern Strategy (Oxford: Oxford University Press, 1999), p. 131.

36. Ali L. Karaosmanoğlu, "Turkish Security Culture: Evolutionary or Carved in Stone" in Peter M.E. Volten, ed., Perceptions and Misperceptions in the EU and Turkey: Stumbling Blocks on the Road to Accession (Groningen: CESS, 2009), pp. 27-46. See also Gencer Özcan, “Türkiye'de Cumhuriyet Dönemi Ordusunda Prusya Etkisi” [The Prussian influence on the Army in Turkey's Republican Period] in Evren B. Paker and İsmet Akça, eds., Army, State, and Security Policy in Turkey (Istanbul: Bilgi University Publication, 2010), pp. 175-222.

37. Şerif Mardin, Religion, Society, and Modernity in Turkey (Syracuse: Syracuse University Press, 2006), p. 182.

38. William Outhwaite, "Hans-Georg Gadamer" in Quentin Skinner, ed., The Return of Grand Theory in Human Sciences (Cambridge: Cambridge University Press, 1994), p. 34.

39. Şerif Mardin, "Turkish Islamic Exceptionalism Yesterday and Today," p. 160.

40. Kemal H. Karpat, The Politicization of Islam: Reconstructing Identity, Faith, and Community in the Late Ottoman State (Oxford: Oxford University Press, 2001), p. 420.

41. Abdi İpekçi and Ömer S. Coşar, İhtilalin İçü̈zü [Inside of the Revolution] (Istanbul: İş Bankası Yayınları, 2010), pp. 3-18. 


\section{A. L. Karaosmanoğlu}

42. Ali L. Karaosmanoğlu, "Officers: Westernization and Democracy" in Metin Heper, Ayșe Öncü and Heinz Kramer, eds., Turkey and the West: Changing Political and Cultural Identities (London: Tauris, 1993), pp. 19-34.

43. Muhsin Batur, Anılar ve Görüssler [Memoirs and Opinions] (Istanbul: Milliyet Yayınları, 1985), pp. 213, 557-9; Nevzat Bölügiray, Sokaktaki Asker [Soldier in the Street] (Istanbul: Milliyet Yayınları, 1989), p. 17. For the views of the last three Chiefs of General Staff, Hilmi Özkök, Yaşar Büyükanıt and İlker Başbuğ, see Murat Yetkin, "Atatürkçü Düşünce Sistemi ve Kemalizmin Reform İhtiyacı" [Atatürkist Thought and the Need for Reform in Kemalism], Radikal (September 28, 2004), p. 6; Murat Yetkin, "Büyükanıt: Kapıkulu Değiliz" [Büyükanıt: We are not the Palace Guards], Radikal (March 29, 2007), p. 6; Murat Yetkin, Interview with General Hilmi Özkök, “AB, Atatürk'ün Vizyonu", Radikal (August 27, 2005), p. 6.

44. See the interview with General Hilmi Özkök, Fikret Bila, Komutanlar Cephesi [The General's Front] (Istanbul: Doğan Kitap, 2010), pp. 182-4.

45. The Chief of General Staff, General Başbuğ's annual speech at the Military Academy, Istanbul, April 14, 2009.

46. Ernest Lopez, "Latin America: Objective and Subjective Control Revisited" (translated by Ian Barnett), in Pion-Berlin, ed., Civil-Military Relations in Latin America, pp. 88-107. 